\title{
O SOM AO REDOR: SEM FUTURO, SÓ REVANCHE?*
}

\begin{abstract}
[*] Os acertos deste texto devem muito às discussões em seminário organizado por Paulo Eduardo Arantes e em encontros com orientandos sob a coordenação de Edu Teruki Otsuka. Agradeço também a ambos, a Roberto Schwarz e a Salete de Almeida Cara pela leitura e por sugestões. Os desacertos correm por minha conta e risco.

[1] As cenas de "realismo mundano", como o chama Kleber Mendonça Filho, figuram algo que, parecendo banal, revela, pelo recorte e pela montagem, a realidade mais ampla. Cf.: "Kleber Mendonça Filho fala sobre O som ao redor, vencedor do festival do Rio", 15/10/2012. Consultado em: www.adorocinema.com.
\end{abstract}

[2] Assim, por exemplo, há relações entre $\mathrm{O}$ som ao redor e Cronicamente inviável (2000), de Sérgio Bianchi, que mereceriam análise mais detida; aqui apenas aponto a similaridade da forma descontínua e da focalização nas classes médias - menos radical em Osomao redor. Também se podem ver certas referências a filmes do cinema novo e do chamado "cinema de retomada", como apontou Lúcia Nagib ("Em 'O som ao redor', todos temem a própria sombra". Folha de S.Paulo, 17/2/1013). Quanto aos thrillers, o diretor cita John Carpenter como um de seus diretores favoritos.

\author{
IVONE DARÉ RABELLO
}

Em suas sete primeiras semanas de exibição, em 2012, Osom ao redor (2012), primeiro longa-metragem de ficção do roteirista e diretor Kleber Mendonça Filho, alcançou um público superior a 70 mil espectadores, o que dá o que pensar em se tratando de cinema brasileiro. Em janeiro de 2014, também devido à boa recepção internacional eà indicação para o Oscar, foram lançados no mercado dois DVDs, com tudo a que tem direito um empreendimento com previsão de bons resultados: filme, versão comentada pelo diretor, making of, cenas não utilizadas, entrevistas concedidas pelo cineasta, gravação de debates e exibição de alguns de seus curtas, como Vinil verde, Recife frio, Eletrodoméstica.

O sucesso, ainda que relativo se comparado aos índices de bilheteria do cinema internacional, pode ser explicado por vários fatores, entre os quais os sagazes flashes da vida contemporânea numa grande cidade, em chave do que Kleber Mendonça chama de "realismo mundano" ${ }^{1}$, aos quais se combina uma narrativa de suspense em que expectativas angustiantes não se resolvem. A esses elementos associam-se a qualidade técnica das imagens e da montagem (do diretor e de João Maria) e a sonoplastia, que, ao funcionar como comentário autoral ao enredo, dá novos significados a ele. Já o público cinéfilo se compraz com referências a outras obras do cinema nacional e a thrillers conhecidos $^{2}$, com autocitações e aproveitamento de curtas do diretor, como Eletrodoméstica (2005). 
Mais decisivo para o sucesso de crítica, porém, é o fato de O som ao redor ter capturado traços que constituem expressiva parcela da experiência social do Brasil contemporâneo ${ }^{3}$.As personagens da classe média recifense - que, com suas particularidades, não difere substancialmente das de outras grandes cidades brasileiras - orbitam em torno de seus anseios de consumo e necessidade de segurança, bem como seentorpecem em desprazeres e tédio. Já os trabalhadores desempenham papéis em que irrompem as figuras do servilismo e do ressentimento social. Também se põe à mostra a permanência de traços da estrutura patriarcal brasileira, no núcleo presidido por Francisco (Waldemar José Solha), proprietário de mais da metade dos imóveis da rua Setúbal e velho senhor de engenho de fogo morto.

O esforço do filme em apreender a experiência social recente dá prova de sua qualidade e contribui para o interesse por ele. Mas ainda não se levou na devida conta, penso eu, o que $O$ som ao redor anuncia como diagnóstico do futuro, na investigação artística sobre as razões pelas quais o Brasil urbano do século XXI convive com formas de mando (ainda que decadentes) do velho Brasil agrário, bem como as consequências dessa mescla num momento em que perspectivas de transformação pareciam rifadas - ao menos até junho de 2013.

\section{A RUA É UM PAís}

Quase toda a ação se concentra na rua Setúbal, no bairro do mesmo nome. Os dados do ambiente são incorporados à fatura da forma cinematográfica, nas locações reais que tingem com estatuto de realidade o queéficção: prédios altos, uniformidade de classe de seus moradores e tranquilidade apenas relativa da região, já que, além do ruído dos aviões, com rota sobre o bairro, há sinais ostensivos do temor de assaltos, com a profusão de grades de segurança. Tudo, à primeira vista, compõe o cenário urbano do país atual. Mas apenas em aparência a vida na rua Setúbal desconectou-se das pesadas heranças do passado agrário. Os arranha-céus não soterraram os modos de exploração que os ergueram, nem a sociabilidade que dominara em outros tempos. A ficção dará conta de dar visibilidade à mescla entre o antigo (será arcaico?) e o contemporâneo.

A novidade do contemporâneo está à mostra: no ambiente urbano, o espaço público não tem presença viva. A rua é um lugar deserto, ou quase: só raras vezes alguém transita por ela, e, quando o faz, trata-se de equívoco ou de urgência, como na cena em que uma mulher desce do carro para vomitar. $\mathrm{O}$ asfalto se presta a comunicações sem interlocução direta, com mensagens de amor escritas para ser lidas pelas janelas ou varandas.
[3] Entre os vários artigos sobre o filme, além do já citado, de L. Nagib: “O som ao redor, de Kleber Mendonça Filho", de Luiz Soares Junior (revista Cinética); "O 'novo' Brasil nas telas: uma análise do filme 'O som ao redor'", de Marco Pestana (blog Convergência); "Um som perturbador" e "'O som ao redor', ou filmes que marcam época" (blog em O Estado de S. Paulo) e "Diálogo entre passado e presente para entender o Brasil" ( $O$ Estado de S. Paulo, 13/1/2014), de Luiz Zanin; "Ao redor do som", de Inácio Araújo (blog do autor no UOL); "O escravismo entre o passado e o futuro", de Joana Salém Vasconcelos (Le monde diplomatique, 7/1/2014); "Obra retrata fim do coronelismo no país", de Maurício Puls (Folha de S.Paulo, 17/2/2013); "O som ao redor: sociedade em ausculta", de Christian Gilioti (Laika, vol. 2, $\mathrm{n}^{\circ} 3$, junho/2013); afora críticas no Time Out Chicago e no Chicago Reader. Apenas Eduardo Escorel avaliou o filme negativamente (cf.: "O som ao redor-violência latente", Piauí). 
Nos espaços privados da classe média urbana, a presença de bens de consumo, reiteradamente expostos pela câmera,éíndice da posição social ascendente. O aumento do patrimônio pessoal engaiola aqueles que, sem laços comunitários ou políticos, são governados por interesses regulados pela mercadoria e vivem sob a tensão permanente de algo ameaçador que estaria por vir. As grades que se multiplicam, do apartamento térreo ao de cobertura, protegem do medo e o atiçam.

Já os pobres surgem nas figuras de trabalhadores informais ou empregados e subempregados domésticos. Nas cenas de rua, flagram-se guardadores de carros, vendedores de CDs piratas, o entregador de água que ganha graninha extra passando droga para enfastiados moradores dos apartamentos ou motoristas que conhecem a boca de fumo itinerante. Não se pode mais falar que esses trabalhadores, muitos dos quais deixaram o campo movidos pela ilusão de ascensão social na cidade, não estejam integrados ao país ou a comportamentos evalores urbanos. Só que sua integração implica e reforça a manutenção da velha estrutura de iniquidades originada do país agrário, acrescentando-lhe novas pitadas. Sem os vínculos da dependência da família patriarcal, deixados de lado há muito, ficam ao deus-dará e exploram as potencialidades do mercado onde elas aparecem, lícita ou ilicitamente. $\mathrm{O}$ vendedor de CDs piratas que põe o volume no máximo para espalhar os sons da música em que o sexo rola solto não dá a mínima para o policial que se aproxima, pois sabe que o objetivo do milico não é confiscar as mercadorias, e sim comprá-las por um precinho mais em conta. Mesmo sem aqueles vínculos diretos de dependência, porém, esses trabalhadores informais temem os poderes que emanam de Francisco, o dono da rua, versão contemporânea do senhor da casa-grande, a quem devem preito incondicional, pois provavelmente depende dele a sua permanência naquele lugar. O Estado não coíbe a informalidade, mas o rei da rua pode expulsar quem quiser. Numa cena significativa, os guardadores de carro não denunciam Dinho, o neto de Francisco, embora saibam que ele assaltara o carro de Sofia (Irma Brown), namorada de João (Gustavo Jahn), também neto do patriarca.

Outros atores sociais emblematizam formas atuais da divisão social instalada com naturalidade nos ambientes privados. Em todos os apartamentos, há empregadas: negras, mulatas, quase brancas. São as "domésticas", função que atualiza a das antigas "crias" da casa, gente lançada à subalternidade aviltante e à ausência de direitos. Num dos esquetes, espécie de contraponto perverso da cena em que a menina de classe média passeia com seus patins pelas dependências do prédio em que mora, a trabalhadora limpa o chão, deslizando os pés sobre um trapo: os velhos tempos, sem eletrodomésticos, ainda vigoram para os que vendem sua força de trabalho a preço de banana. Mas os novos 
tempos também trouxeram conquistas. Nos prédios de construção recente, já há minijanelas nos cubículos destinados às empregadas; algumas "domésticas" têm direitos trabalhistas, como Mariá, a empregada de João, que, registrada, está prestes a se aposentar; não faltam sequer as hierarquias na carreira, como se vê nos flashes na residência de Francisco, quando uma das empregadas, cuja ascendência fica assinalada pelo fato de morar no apartamento do patrão (o quartinho com banheiro em um canto escondido da cobertura), organiza as outras, gerenciando tarefas e atendendo à porta.

Nesse conjunto social, o servilismo dos trabalhadores mostra sua contraface em pequenos atos vingativos, sem objeto ou alcance precisos. São estratégias de revanches veladas, como resposta a ressentimentos acumulados. A empregada de Francisco quer dormir com o amante na cama branca de outros patrões; sua vingança pelas pequenas humilhações cotidianas não supõe nem implica (e como poderia?) projeto algum.Adiarista de João responde com obediência silenciosae cheia de rancor aos cuidados paternalistas do patrão, que não quer que ela passe roupas com os pés descalços. O guardador de carro humilhado não hesita em riscar o carro da mulher que o maltratou, desde que o faça às costas da madame. Não há enfrentamento de classe, até porque cada um dos trabalhadores está isolado, sem sombra de alguma organização que lhe permita juntar-se aos seus para criar estratégias de transformação. Sobram a desforra simbolicamente compensatória ou a revolta surda4.

Na relação entre empregadores e empregados, é exemplar a cena em que o síndico do condomínio traz à pauta da reunião o caso do zelador que, tendo ele próprio escolhido o turno da noite por lhe render ganho adicional, não faz mais que espiar, por prazer voyeurista, o que ocorre nos elevadores equipados com câmeras de segurança e dormir quanto pode. Dorme, e sem disfarçar, como revela o filme feito pelo garotinho, herdeiro promissor, armado com suas câmeras de celular e computador. Uma queixa leva à outra, e a moradora suscetível reclama de ter recebido sua Veja sem o plástico de proteção. Tudo que se passa antes da votação - palavras de descontentamento e irritação, caras e bocas - aponta para a aprovação da demissão por justa causa. Mas, com voz mansa, João, espécie de condômino esclarecido, advoga a causa do trabalhador e pretende praticar a ética do bom patrão, propondo a demissão com direito a indenização. Só comove um gringo, mas não a ponto de este não se informar sobre quanto lhe custaria a boa ação. $O$ valor de trezentos reais para cada condômino (como se isso depauperasse os proprietários) elimina qualquer veleidade. Com provas documentais, a demissão por justa causa é a vitória da lei, para a qual se apela quando está em jogo dispêndio de dinheiro. Vínculos pessoais são coisa do passado.
[4] Apenas uma das empregadas reage à humilhação da patroa enfrentando-a e defendendo a dignidade pessoal de quem vende sua força de trabalho. Quando, às voltas com as tentativas de fazer os latidos do cão da casa vizinha deixar de (segundo o que ela acredita) provocar-lhe insônia, Bia (Maeve Jinkings) compra um aparelho antilatido - "importado!" - e percebe que a empregada, por não ter lido o aviso sobre a voltagem, queimara-o, censura-a aos berros; a doméstica, então, retruca: “A senhora pode descontar do meu salário. Não precisa gritar. Não precisa falar desse jeito". Índice histórico do orgulho dos que vêm de baixo, da era Lula? 
No polo oposto do espectro social dos trabalhadores pouco qualificados, surgem os "donos da rua", espécie de máfia à brasileira. Francisco, o senhor do engenho desativado, é, no presente da narrativa, o latifundiário urbano:proprietário de quase todo o terreno da rua Setúbal, agora é dono de mais da metade dos edifícios, muito altos, e também de uma imobiliária; na rua, restam poucas casas, uma das quais ocupadas por seu filho Anco (Lula Terra). A família não faz mais do que administrar os bens do patriarca, por meio dos empregos (melhor seria dizer sinecuras) na empresa do avô, e dar sobrevida à mentalidade patriarcal, tingindo-a, como revelam as ações de João, com algumas modalidades esclarecidas da sociabilidade, devidas à hora histórica que a põe em risco. Só até certo ponto, claro.

Originário da exploração colonial e do escravismo (especialmente nas regiões de exploração de cana-de-açúcar, como Pernambuco), e edificado nas relações de parentela, familismo, cordialidade, o mando patriarcal, que não se esgotou com o fim da escravidão, está sob ameaça: precisa mudar para tentar permanecer, em circunscrição apequenada. A exploração da grande propriedade não tem mais vez, ao menos nos mesmos termos; os domínios do "coronel" Francisco são agora o reino da exploração imobiliária, na locação e administração dos apartamentos. Já não há, na cidade, nem a casa-grande nem o sobrado que congregue agregados à sua volta e confirme a superioridade do patriarca, o que não impede, porém, que a dominação e a prepotência persistam com permanências e alterações.

As derivações do patriarcalismo se corporificam nos netos de Francisco. João é a personagem em que o argumento se detém. Após viver sete anos na Alemanha - com alguma ingênua intenção de autonomia, pois, embora decerto recebesse mesada, atuava como garçom em bares noturnos -, retorna ao lar e, mesmo detestando o que faz, trabalha. Mas não se cansa: como neto herdeiro e corretor dos imóveis da família, na imobiliária do avô, pode dispor de seu tempo com bastante folga; as visitas agendadas não o impedem de perambular, conversar, namorar durante o dia. Em seu apartamento, as relações entre ele e Mariá, a velha empregada da casa, estão e não estão subordinadas ao trato moderno:ela nãoé a "cria" da casa, pois está submetida ao regime das leis trabalhistas; no trato entre eles, porém, a regra é a cordialidade do patrão, na mescla de impessoalidade e pessoalidade regida a rompantes instáveis de simpatia ou antipatia, sempre comandados pela volubilidade astuta. Assim, por exemplo, quando as netas de Mariá ficam em sua casa e perambulam à vontade, João as abraça, conversa com elas, dá-lhes livre trânsito. Mas, quando o proprietário chega em casa e vê o filho da empregada cochilando em seu sofá, não fica nada satisfeito, e é Mariá quem, percebendo o agastamento do proprietário, age por ele, exigindo que o filho acorde. Embora não censure o 
garoto, João amavelmente lhe dá trancos formidáveis, dizendo que era assim que seu "velho" o acordava; desse modo, dá um jeitinho de agredir esse agregado indesejado, ao mesmo tempo em que se equipara a ele. Levando-o à área de serviço, comenta as similaridades de suas experiências de trabalho; nas dependências pouco nobres do apartamento, João o trata como um igual, pois, segundo o herdeiro rico, ambos conhecem a dureza do expediente noturno e aprenderam que o trabalho dignifica. O cinismo sincero não contradiz o bom-mocismo, assim como as atitudes esclarecidas não entram em curto-circuito com aquelas cordialmente paternalistas. Tudo pode ser conciliado. Órfão de pai e mãe, João constrói sua vida certo de sua origem - "sou um homem rico", diz à namorada -, mas tem esperteza e capacidade para modificar e atualizar as condutas patriarcais do avô. Por que faria algo diferente disso?

Já Dinho, apresentado como personagem plano, é o "marginalzinho" que causa desgostos à família, que, não obstante, o protege de qualquer punição impessoal. Versão degradada do poder patriarcal, seu destino histórico beira a perpetuação da criminalidade impune. Cioso da posição de herdeiro, não se cansa de mostrar sua desfaçatez de classe: ele pode tudo, os pequenos furtos servem-lhe como diversão. Desde que, claro, conte com a proteção do avô. Ele parece estar seguro da sobrevida poderosa do que pode estar agonizante.

No conjunto de $\mathrm{O}$ som ao redor, gravitam trabalhadores informais, empregados domésticos, classe média e herdeiros da classe dominante. A escolha do cineasta exclui os setores proletários e os verdadeiros donos da riquezas ${ }^{5}$ o que não necessariamente limita a realização artística ${ }^{6}$. Na análise da obra, interessa saber qual a função exercida pela estruturação artística dessa realidade historicamente restrita e qual a interpretação dada ao material.

Na rua Setúbal ninguém fala com ninguém, sabe-se o suficiente sobre a vida dos outros, e tudo se integra na rotina do trabalho e da acumulação e defesa dos bens ${ }^{7}$. Em cenas fragmentárias que indicam não haver coesão de agentes sociais, o que se impõe é o isolamento do conjunto dos moradores, todos eles enjaulados em seus apartamentos, e a vida ao deus-dará dos trabalhadores. Não há, também, nenhuma perspectiva de transformação, pois os núcleos narrativos repõem o mesmo, em idas e vindas que não atingem a consecução das pequenas finalidades desejadas (o namoro entre João e Sofia mal começa e já termina, o latido do cão que perturba Bia não se resolve, a rotina dos dias repõe e alimenta os mesmos medos). Fragmentação, isolamento e repetição, que mapeiam a sociedade urbana contemporânea aos olhos do roteirista diretor, indicam que os conflitos, anódinos, não se desenvolvem senão nas esferas privadas da ordem social. Esse o momento novo que o filme captura e interpreta, assinalando a inexistência da dimensão política transformadora.

\begin{abstract}
[5] Já em Boa sorte, meu amor (2013), filme de estreia do também pernambucano Daniel Aragão, o trajeto do protagonista Dirceu (Vinicius Zinn), que, como João, descende de proprietários rurais do sertão pernambucano, revela as forças menos visíveis da riqueza no Recife, isto é, a exploração fundiária, e no sertão, com os altos lucros dos investidores nas obras de transposição do rio São Francisco.
\end{abstract}

[6] Memórias de um sargento de milicias, de Manuel Antonio de Almeida, é o exemplo mais contundente de alta realização estética em que, apesar do panorama social restrito, sem a presença das camadas dirigentes e dos trabalhadores (no caso, os escravos), a estrutura social profunda do Brasil está formalizada (cf. Antonio Candido, "Dialética da malandragem", em $O$ discurso e a cidade. São Paulo: Duas Cidades, 1993, pp. 19-54).

[7] Ou quase, como se insinua na referência à moça suicida, embora também o suicídio possa ser um elemento que atua como mercadoria ou barganha: a mulher interessada no imóvel onde ocorreu o fato pede um desconto no valor do aluguel porque, além do mau agouro, isso desvalorizaria o prédio. João, que não depende do emprego para sobreviver, não deixa por menos: eliminando qualquer possibilidade de atender à demanda, tripudia sobre a falácia argumentativa da interessada e suas superstições: "Não vejo a relação. O que aconteceu não muda em nada a qualidade desse lugar. $O$ apartamento não é mal-assombrado". 
[8] Vejam-se, a respeito, os escritos de Roberto Schwarz, especialmente "Final de século" e "Nunca fomos tão engajados", de Sequências brasileiras (São Paulo: Companhia das Letras, 1999). De "Agregados antigos e modernos" (entrevista), de Martinha versus Lucrécia (São Paulo, Companhia das Letras, 2012), destaca-se o trecho: "Desde então [época de Joaquim Nabuco], até a crise do nacional-desenvolvimentismo, nos anos 1970, a transformação dos excluídos em assalariados rurais, operários e cidadãos fez parte do ideário progressista. Sobretudo através da industrialização e da reforma agrária, que prometiam reformar o país, acabando com a liga de mandonismo, miséria, clientelismo, subcidadania etc., que nos separavam da modernidade. Com a globalização, essas expectativas passaram por uma redefinição drástica. Para desconcerto geral da esquerda, a modernização agora se tornava excludente e reiterava a marginalização e a desagregação social em grande escala. Para quem não sabia, o progresso do capital e o progresso da sociedade poderiam não coincidir" (p. 178).

[9] A expressão é utilizada por Paulo Eduardo Arantes, em "A fratura brasileira do mundo", de Zero à esquerda (São Paulo: Conrad, 2004).

[10] Não se trata de mera coincidência, ou apenas reconhecimento da qualidade estética do cinema brasileiro, o fato de $\mathrm{O}$ som ao redor ter sido objeto de interesse da crítica e de premiação em festivais nos Estados Unidos, Canadá, Inglaterra, Sérvia, Polônia.

[11] Para Lúcia Nagib, O som ao redor apresenta "o reverso do paisagismo grandioso que caracterizou o Brasil no cinema novo e depois no cinema da retomada, o sertão imenso e as imagens de mar prometendo, e continuamente frustrando, a realização utópica do paraíso sonhado pelo colonizador europeu" (artigo citado).
Nesse sentido, os conhecimentos revelados pela chamada "tradição da formação", especialmente os estudos de Sérgio Buarque de Holanda, Caio Prado Júnior, Celso Furtado e Gilberto Freire, e que hoje fazem parte do repertório esclarecido que Kleber Mendonça reconhece como seu, estão longe de dar conta das questões que descrevem o presente, embora também prossigam existindo as formas da sociabilidade por ela descritas e categorizadas. No andamento contemporâneo - para o qual derrotas históricas e equívocos interpretativos contam bastante - o país periférico perdeu a corrida para alcançar as nações centrais, para usar os termos com que se pensava certo modelo de desenvolvimento e de integração do país.

Aliás, desde muito antes dos anos em que a via do desenvolvimento da indústria e da integração dos setores inorgânicos da população pautava as perspectivas de transformação do lugar do Brasil no concerto das nações, a economia e a vida material e simbólica dos países periféricos estavam articuladas ao desenvolvimento do capitalismo mundializado. No entanto, nos anos do nacional-desenvolvimentismo, havia (ou se avaliava que houvesse) um horizonte aberto, e se acreditava que as lutas políticas tornariam possível a superação do atraso. Desdeos anos 1980, e sem mais dúvidas de queo país está plenamente inserido na nova ordem do desenvolvimento capitalista, o horizonte de expectativas desaparece, ou quase. Avanço da modernização e degradação das condições de vida (não só na periferia) se reafirmam como unidade contraditória indiscutível na ordem capitalista mundial, e, nas novas condições tecnológicas, se tornaram inalcançáveis para o país os recursos necessários para completar a industrializaçãoe a integração social ${ }^{8}$. Em tempo de brasilianização do mundo9, o Brasil devolve ao centro a imagem de seu próprio futuro ${ }^{10}$.

Apreendendo esse momento decisivo e estilizando-o, trata-se, para o artista, de interpretá-lo com as armas e os pontos de vista de que dispõe. Para Kleber Mendonça Filho, em nosso presente híbrido, aparentemente eterno, em que velhas formas de mando agonizam mas não morrem, e em que o verdadeiro poder permanece fora da cena (onde os detentores da riqueza financeira?; ondeo Estado?), parece ter desaparecido tudo que move à superação.

\section{UM PAÍS BLOQUEADO}

A rua de classe média do Recife figura uma interpretação do Brasil contemporâneo. Não resta nenhuma ilusão mítica ou pitoresca' ${ }^{11}: \mathrm{mal}$ se vê o "belo mar selvagem", enfrentado com coragem e orgulho apenas por Francisco, o representante do velho e ainda atuante poder. $\mathrm{Na}$ trama das relações sociais, as estruturas de iniquidades decorrentes do passado histórico, bem como suas consequências destrutivas, asso- 
ciam-se, sem perturbações, aos novos dinamismos sociais impostos pelo processo em curso do capitalismo atual. Mas a desconexão aparente entre as tramas soltas das diferentes personagens, que constitui boa parte da composição, intriga e faz pensar.

A começar pelas duas sequências iniciais do filme. Elas se compõem de um jogo técnico de oposições: branco e preto/cor; fotos/ação em curso; passado documental sem localização precisa/ficcionalização da vida contemporânea com o uso de locações reais.

A primeira sequência apresenta, uma a uma, um conjunto de dez fotografias em preto e branco que retratam eventos históricos e fatos culturais. Algumas delas, senão todas, parecem ter como referente a Superintendência do Desenvolvimento do Nordeste(Sudene), criada por Celso Furtado em 1959, a pedido de Juscelino Kubitscheck. O economista, como se sabe, foi um dos intérpretes da "tradição da formação", que considerava indispensável integrar os setores atrasados do país ao modelo avançado, no esforço por superar o que se considerava tanto o dualismo interno do país quanto sua condição periférica no concerto das nações. O latifúndio e seus coronéis, a quem interessava a mão de obra superexplorada, teriam de ser enfrentados por meio de novas formas de desenvolvimento, implementado por incentivos fiscais, e a indústria deveria ser implantada também na região agrária, "atrasada". Os setores que se juntaram para a criação da Sudene, como as Ligas Camponesas e segmentos progressistas da Igreja Católica, articulavam-se para contribuir na luta por direitos dos trabalhadores rurais e distribuição de terras. No horizonte entrevisto e desejado pela esquerda, os combates por reformas e a combinação de desenvolvimento agrário e industrial poderiam fazer avançar o ritmo para permitir o salto revolucionário.

É esse conjunto de referências que a primeira sequência de $O$ som ao redor documenta. Em poucas palavras: o retrato do momento em que o projeto do nacional-desenvolvimentismo, tal como ocorria no campo, surgia como possibilidade histórica de transformação. Mas, congelado nas imagens sem movimento próprio, na abertura do filme, esse momento surge como testemunho do futuro em país bloqueado. Como se sabe, o golpe militar de 1964 derrotou as esperanças; massacrou lutas e corpos. O progresso do capital e os investimentos maciços das multinacionais, com as vantagens oferecidas pela ditadura, reiteraram e agravaram a desagregação social, num país que efetivou nova etapa de sua modernização sob o comando dos interesses do capital internacional.

O som cinematográfico que acompanha a sequência das fotos, a partir do ângulo do presente, interpreta a ação interrompida ali pressuposta. Sem fonte identificável nas imagens, o som de bumbos em crescendo, numa espécie de marcha guerreira, insinua algo que pode 
[12] O cineasta se vale da música "Cadavres en série", de Serge Gainsbourg e Michel Colombier, composta para o filme Le Pacha (1968), de Georges Lautner, cuja trama se concentra em disputas entre membros do corpo policial. Sua reutilização associada ao desfile das fotos decerto ganha significações surpreendentes.

[13] Lúcia Nagib, no artigo citado, comenta a cena como inversão paródica do final de Deus e o diabo na terra do sol (Glauber Rocha, 1964), em que o travelling de Manoel correndo em direção ao mar nunca visto sugeriria, segundo Ismail Xavier, a teleologia da história.

[14] Interessante notar que, na cena da entrega do aparelho de TV, a reação da vizinha se aproxima das cenas descritas na subliteratura ambientada em cortiços: quer arrancar os cabelos da vencedora, como se a TV fosse o amante disputado.

[15] Tédio e ânsia insaciável por objetos e imagens enfeitiçados não se limitam a esta ou àquela dona de casa enfastiada. As crianças também os vivenciam: a bola perdida no terraço de um edifício é facilmente substituída pelo videogame; as filhas da empregada de João se anestesiam com programas televisivos (infantis?) em que sexo e entretenimento parecem se acoplar gozosamente. ou poderia vir a ameaçar a todos ${ }^{12}$. Naquele momento de derrotas, iniciar-se-ia uma marcha de cadáveres ou de uma turba de vingadores. Mas sua vinda à cena histórica não ocorreu nem tem data marcada. $\mathrm{Na}$ ambiguidade proposta pela sonoplastia, trata-se de presságio, desejo de futuro ou percepção do que está em andamento no presente?

No entanto, a abertura sugestiva é cortada abruptamente pela nova sequência: o espectador acompanha, pelos olhos da câmera, a cena urbana do presente, em cores; ouvem-se risos e falas entrecortadas de crianças brincando. Uma menina desliza em seus patins, entre vãos da garagem de um edifício cercado por grades de segurança $a^{13}$, e chega ao playground, onde há muitas crianças e babás. O espaço que se anunciava como conviteà amplitude se fecha num retângulo pequeno, circundado por murose mais grades; alguns meninos, curiosos, olham para o que está do lado de fora. O ruído irritante que aos poucos se sobrepunha ao som da meninada encontra seu referente:um trabalhador fixa uma grade novinha na janela de um apartamento do térreo.

O corte das sequências é a forma artística da brusca sugestão de uma continuidade histórica. É como se dissesse que a contemporaneidade, tal como a vemos, nasce da derrota do que se imaginou, ao final da década de 1950, como possibilidade de transformação. No enredo, porém, a derrota das promessas de superação do Brasil inorgânico, tal como ela se impôs a partir do golpe de 1964, parece constituir um fio solto, sem se articular à política contemporânea e à vida nas grandes cidades.

Até que se retome o fio e se explicite a causalidade entre dois momentos históricos, a composição se organiza apresentando cenas breves que, acumulando pequenas narrativas sobre moradores da rua Setúbal, captam aquilo que se tornou a vida governada pela mercadoriae suas consequências na vida psíquica das classes médias. É o caso das sequências com Bia, que, com enfado, e cercada por eletrodomésticos, cuida da casa, administra e controla a vida dos filhos, já grandinhos. Com o marido, pretende assegurar o futuro deles, investindo em seu capital imaterial (com aulas de inglês e mandarim, suprassumo do acesso ao futuro em tempo de BRIC). Seus olhares, porém, em closes reiterados, traem a insatisfação que preside às relações mediadas pela mercadoria. A cena da agressão repentina de sua vizinha contra ela, motivada pelo tamanho maior do novo aparelho de TV, dá a medida da disputa pelos pequenos poderes ${ }^{14}$. Bia oscila entre orgulho e tédio, medo e ansiedade. Para aliviar-se dos desprazeres, não resiste nem às trepidações da máquina de lavar nem à "brisa" trazida pela maconha que, no entanto, expira no bocal do aspirador, de maneira a que nada recenda prazeres ilícitos ${ }^{15}$.

As tramas sem articulaçãoentre elas, montadas em sessões descontínuas, se concentram na vida privada das personagens, sem comuni- 
cação entre si. Mas a chegada de uma equipe de segurança privada que quervender seus serviços reunirá vizinhos, promoverá discussões e irá atar o fio descontínuo do enredo.

Organizando o desenvolvimento da trama, as rubricas anunciam o conjunto dividido em três capítulos: "Cães de guarda", "Guardas noturnos" e "Guarda-costas". Os títulos, com as diferenças de agentes (cães, homens e capangas), assinalam não apenas um mesmo fenômeno, mas sobretudo sua intensificação: a necessidade de defender a propriedade privada é diretamente proporcional à ameaça (fantasmática ou não) que paira sobre as coisas e os corpos. O crescendo da narrativa, insinuado na sequência das rubricas, sugere que o cão de uma casa não serve para nada quando se trata do medo coletivo dos habitantes dos edifícios, que, já acostumados com furtos constantes de aparelhos de CD nos carros parados nas ruas, precisam proteger-se com grades e cadeados. A ilusão da segurança, para a classe média, compõe-se do consumo da parafernália moderna que torna obsoleto o animal de guarda e seus incômodos latidos. Como, porém, os acessórios não bastam, as empresas privadas de segurança têm sua chance de empreendedorismo, ao vender a imagem de que guardarão as costas e os bens materiais dos moradores sem rosto. Essa forma da proteção, moderna e em certa medida impessoal, traz consigo reminiscências da capangagem. Por isso mesmo, não surpreende que Francisco, como bom latifundiário, ao perceber sinais de que há inimigos pessoais à solta, proponha aos guardas noturnos que se tornem seus guarda-costas, prática que remonta aos abusos das elites patriarcais e se mantém como norma.

De todo modo, a defesa do território e a violência, que estão na origem da existência de cães de guarda e de guarda-costas, se naturalizam na venda da segurança, a qual, porém, não engana ninguém. Como percebem Bia e Anco, a coerção cordial a que os moradores ficam sujeitados quando recebem o convite para usufruir dos novos serviços da rua, traz novos perigos: quem não pagar pode se tornar vítima. Feitas as contas, a mercadoria segurança é um bem indispensável porque protege especialmente de novos fantasmas do medo. Furto, roubo, latrocínio, invasão da propriedade, morte, vingança, turba revoltada são os temores, manifestos ou latentes.

A empresa que apresenta seus serviços de modo afável é comandada por aquele que se apresenta como Clodoaldo Pereira dos Santos (Irandhir Santos), mas para que ela vingue é necessária a "bênção" do dono da rua, sr. Francisco Oliveira ${ }^{16}$. A condição para que consinta nas atividades dos seguranças é que eles não mexam com seu neto, Dinho - membro do território familiar sobre o qual ele imagina ainda exercer domínio inquestionável.
[16] A escolha desse nome decerto remete ao (quase) homônimo Francisco de Oliveira, um dos fundadores do PT, que, há alguns anos, expõe suas críticas ao partido e aos rumos do lulismo. 
[17] Atualmente, Bonito é uma região turística em que se vende a beleza das cachoeiras. No entanto, ali se travaram lutas e massacres de escravos e de camponeses: no século XVII, estabeleceu-se o Quilombo dos Palmares; ao final de 1819 , na serra do Rodeador, ocorreu revolta messiânica contra a miséria, liderada por Silvestre José dos Santos; em dezembro de 1874, a Revolta dos Quebra-Quilos.
A infraestrutura do trabalho da empresa que vende a mercadoria segurança alia a precária tendinha de praia aos modernos celulares. Os aparelhos permitem o controle de toda a rua e a intercomunicação entre os pares; também servem como uma espécie de "educação policial": exibindo aos membros de sua equipe um filme com as tomadas da morte de um segurança da rua, guardado na memória do celular, Clodoaldo ensina-lhes como é preciso estar alerta. Assim, para a segurança da empresa, os aparelhos são instrumentos que agilizam a comunicação e são também uma arma. Os fatos, pressupõe-se, precisam estar documentados, para que possa haver cobrança de justiça. De algum modo, torto, reverberam, em continuidade alusiva, as fotos da primeira sequência do filme. Quanto às outras armas, Clodoaldo, esperto, não diz nem que as tem nem que não as tem.

Mesmo que o próprio Francisco assegure que com a chegada da equipe "a rua tem segurança", a função do grupo, ao menos de início, limita-se a espiar a vida privada, observar os bêbados, ajudar os que se perderam. Afinal, o bairro é tranquilo. Mas, contraditoriamente, também intimida sem rodeios. A primeira ameaça, sem que haja motivação realista aparente, volta-se para o marginalzinho da elite. Sem mais nem menos, Clodoaldo, resguardado pelo que supõe ser o anonimato de um telefonema em orelhão de rua, disca para a casa de Dinho e, com toda a calma, afirma que terminarão as ações ilegais do jovem. A falta de coerência entre a ação de ameaçar um morador e a de garantir segurança ao conjunto deles insinua outro patamar de tensões, já que Clodoaldo desobedece às ordens de Francisco e seu ato parece desmando implausível daquele que se submetera às imposições do dono da rua. O filhote de mandante, porém, não hesita:vê registrado em seu celular o número discado, percebe que se trata do número do telefone público de sua rua e sai de casa à noite para ameaçar os seguranças. De quebra, aproveita para humilhá-los marcando o abismo social entre eles, com a fineza dos que ostentam suas origens e menosprezam todos os que não compartilham de seu pedigree, lançando-os à vala comum dos mais pobres: "Essa rua é de minha família. Gente grande, de dinheiro. Essa rua não é favela".

A fonte da riqueza da família de Dinho nasceu da exploração do braço escravo. Não se trata de acaso o fato de ser a casa de engenho, na região de Bonito ${ }^{17}$, o lugar com que Francisco se identifica e onde deseja reunir os seus. O engenho, porém, são carcaças onde vigora o mato, e as máquinas estão paradas, enferrujadas. Fogo morto. Quase tudo por ali se limita ao que foi, até mesmo o cinema desativado, em ruínas, em cuja fachada resta um lambe-lambe com propaganda política do PSDB, a que, assim, o filme alude como carcaça do passado. Viva mesmo, apenas a escola rural, onde a meninada, na varanda, tem aulas com métodos ultrapassados que, não obstante, lhe causam prazer e risos. 
A cena mais alegórica do filme (e nem de longe a melhor) ocorre na região de Bonito: na cachoeira em que Francisco, João e sua namorada Sofia recebem no corpo a violência da queda d'água, subitamente a água se transforma em sangue - para os espectadores, apenas. Com algum ranço pedagógico, ensina-se ao espectador que desconhece as origens da riqueza do patriarcado brasileiro a fonte assassina das fortunas, de maneira a produzir estranhamento com a quebra do registro realista em locação real. No sangue dos corpos mortos dos trabalhadores escravos, que simbolicamente continua jorrando, os proprietários se deliciam. Eles não veem isso, claro; apenas gozam da força da natureza que lhes provoca urros enérgicos de valentia.

Ao lado da casa-grande de Francisco, casarão sem luxo, a senzala assusta e intriga os namorados que a visitam. Ouvem ruídos cujo referente fica em aberto: moradores fantasmagóricos?; aparições sobrenaturais de escravos?; sons de passos do velho patriarca que se angustia pelo mando perdido e se recusa a abandonar seus emblemas mais caros?

Também no cinema abandonado da vila, onde só restam paredes caídas e mato, João e Sofia escutam sons assustadores, sem referência realista: gritos de gente torturada, lamentos lancinantes, mortos redivivos?; trata-se de um jogo autoral com referência a thrillers que homenageiam os cineastas favoritos do diretor?; ou ressurge, para o casal esclarecido, o clamor dos trabalhadores, mortos e vivos, contra os maus-tratos? O temor recalcado e a irresponsabilidade histórica diante das atrocidades do passado são tamanhos que Sofia os exorciza com o jogo do susto: "Buh", faz ela para João, e assim os risos pretendem aplacar apreensões e consciência culposa. Por artes da montagem, o espectador, que contempla a cena com uma atitude que oscila do distanciamento à identificação, se vê metido no mesmo esconde-esconde. Atormentada pelo horror ancestral de que os excluídos do banquete da existência retornem para reclamar seus direitos, a classe dominante se vale do conjuro divertido e da brincadeira de lançar os inimigos para o imaginário de filmes de monstros. Mas os mortos-vivos, escravos e trabalhadores livres, regressam fantasmaticamente para seus antagonistas de classe como o sinal do perigo que é preciso esconjurar. A turba desses monstros, os inimigos de classe, certamente cresceu ao longo dos tempos de exploração desumana. Tudo que o mato comeu - produção e formas antigas da riqueza - não eliminou o passado de violência brutal.

De fato, a violência brutal está à solta, sob a forma de cenas realistas e surrealistas, no engenho e na rua Setúbal. Uma das mais impressionantes tomadas em chave de "realismo mundano" é a do ataque contra um menino negro, franzino, que, escondido no alto de uma árvore, é apanhado pela equipe de Clodoaldo e recebe socos violentos no ros- 
[18] Em entrevista à revista Hammer to Nail (Los Angeles), em julho de 2012, Kleber Mendonça Filho relata que havia no Recife um garoto conhecido como menino-aranha que, dos 14 aos 18 anos de idade (quando foi assassinado), utilizava cabos da companhia telefônica para entrar nos apartamentos dos edifícios. Ali roubava ou simplesmente permanecia para descansar. A história se tornou uma lenda urbana. $O$ diretor quis mencioná-lo em seu filme nessa sequência (cf.: http://www.hammertonail.com/interviews/a-conversation-with-kleber-mendonca-filho-neighboring-sounds).

[19] Só uma dessas fantasmagorias remonta ao devaneio nostálgico: Anco olha para a rua asfaltada, cercada de edifícios, mas vê (e os espectadores com ele) o cenário da rua de terra, com casas avarandadas e ajardinadas.

[20] Há no conjunto dessas cenas alguma similaridade com $O$ invasor (2001), de Beto Brant (adaptação do esboço do romance homônimo de Marçal Aquino, terminado depois do lançamento do filme). No filme de Kleber Mendonça, a cobrança dos de baixo fica apenas anunciada nas fantasias do medo; em $\mathrm{O}$ invasor, o conflito de fato se estabelece: o matador de aluguel, contratado para eliminar um dos sócios de uma empresa, não se contenta com o pagamento do serviço e exige tudo o que os outros dois têm.

[21] Em seminário na FFLCH/USP (setembro de 2013), Paulo Eduardo Arantes observou, retomando indicação de Christian Gilioti, que a referência à idade da aniversariante (13) e o número 45 , na propaganda política no cinema abandonado em Bonito, aludem ironicamente ao Partido dos Trabalhadores e ao PSDB. to ${ }^{18}$. Um dos seguranças pressente que o garoto não é um ladrãozinho; mesmo assim, acha que precisa lhe ensinar seu lugar de modo que nunca mais ouse voltar àquela rua elegante. Entre os iguais, o que vale é a diferença presumida.

Já as cenas de tonalidades surrealistas referem-se às inquietações das classes temerosas de ter bens e corpos ameaçados ${ }^{19}$. A primeira das fantasias temerárias, com mais forte teor de verdade histórica, surge nas imagens oníricas em que homens descamisados, negros, invadem a casa vazia onde a empregada de Francisco mantém relações sexuais com Clodoaldo. Ela, porém, nada percebe, até porque fantasmagorias como essas estão na contramão das revanches imaginariamente compensatórias tramadas pelos humilhados sem consciência de classe. As pequenas desforras da moça contra o patronato não lhe causam pesadelos de angústia nem laços de irmandade com os despossuídos. Apenas o espectador contempla o que paira como sinais de alerta. É com ele que a cena se cumplicia.

De outro quilate é o delírio da filha de Bia. Numa noite, ela se levanta e vai até o quarto dos pais. Eles não estão lá, tampouco o colchão onde dormiam. Vai até o quarto do irmão: estrado vazio, sem colchão e sem irmão. Coisas e corpos desapareceram, sem rastros de sangue. A menina caminha, sai do apartamento, dirige-se ao hall do edifício, e, através de seus olhos, o espectador vê multiplicar-se uma turba de homens negros pobres que toma a rua e invade a entrada do edifício. Corte abrupto: a garota, tão astuta e cujo futuro promissor está imaginariamente assegurado, sonha acordada. Nela se canaliza o medo de classe, nas versões infantil (perde os pais) e adulta (os moradores estão na iminência de ter seus apartamentos invadidos pela corja ${ }^{20}$.

As fantasmagorias - contempladas por personagens ou apenas por espectadores - trazem à cena da vida ficcional o que na vida real se entrevê com terror: na ótica dos de cima, o retorno do recalcado da escravidão se funde, em bandos que surgem no meio da noite, ao exército espectral dos descamisados de hoje. A visão alucinada dos vultos dá corpo aos pavores das classes média e alta de que a luta de classes tome de assalto, em confronto direto, a propriedade e os corpos individuais. O salto moderno não desmanchou o passado, transposto em formas da iniquidade contemporânea que, sem horizonte de organização dos de baixo, movem apenas à desforra.

A revanche - como algo suspenso no ar - acaba por trazer o fio de continuidade rompido na sequência de fotos da primeira tomada do filme. Após a comemoração do aniversário de uma neta de Francisco - que completa 13 anos ${ }^{21}$ ao som da "Canção de cordialidade: feliz aniversário", de Villa-Lobos e Manuel Bandeira -, o patriarca chama Clodoaldo para uma conversa. Dessa vez, é na sala que o recebee a seu irmão que, esclarece Clodoaldo, acabou de chegar do Paraná (como 
ninguém perguntou nada, a explicação provoca suspeita, ao menos no espectador). Para Francisco, interessa negociar novo contrato de prestação de serviços, o que exige trato cordial em tonalidade diversa, como que de igual para igual.

Os irmãos recebem a proposta de serem guarda-costas do velho senhor de engenho. As razões para isso são expostas minuciosamente. Francisco conta que Reginaldo, ex-administrador de suas terras e amigo pessoal, fora assassinado no dia anterior. $\mathrm{O}$ homem o servira por muito tempo e havia mais de dez anos se tornara pacífico, devotado à religião "crente". O velho pressente que a morte de Reginaldo é um sinal que exige ações preventivas imediatas. Durante o diálogo, o close no rosto do irmão de Clodoaldo não deixa dúvidas: num misto de determinação e impiedade, seu olhar indicia haver um plano na iminência de se cumprir. Enquanto isso, Clodoaldo pergunta ao velho por que ele teme que o matador à solta o ataque. Ainda dono de si, Francisco retruca com autoritarismo: não dará explicações a eles; quer apenas contratar um serviço. Finalmente, a tensão se explica e o enigma se desfaz: o irmão de Clodoaldo diz que ambos estiveram com Reginaldo. O olhar do patriarca elimina a necessidade das palavras: já compreendeu a explicação que (nos) é dada por um dos dois sobreviventes do massacre local. Em 27 de abril de 1984, pai e tio dos irmãos foram assassinados por causa de uma cerca. Sem que os irmãos precisem identificar o mandante e o autor do crime, o próprio Francisco se denuncia, dizendo o nome daqueles camponeses assassinados: dele emanara a ordem cumprida pelo fiel capanga Reginaldo. Francisco levanta e também Clodoaldo, agora apresentando seu verdadeiro nome - Clodoaldo José do Nascimento. O corte da cena impede que o espectador saiba como se dá o desenlace da tensão, paralisada.

A se confiar na composição artística do material, a luta coletiva pela posse da terra, derrotada ao tempo das Ligas Camponesas, limitou-se, desde o golpe de 1964, à tentativa individual da defesa da pequena propriedade, pouco apta, porém, a vencer os interesses dos grandes proprietários $^{22}$.Para os irmãos Nascimento, que eludiram sua identidade, que, com a cumplicidade de alguns amigos, montaram a empresa de segurança como estratégia para ter acesso ao assassino do pai e do tio, que contaram com o planejamento racional de ações para subjugar a emoção, a batalha se organizou na direção da vingança pessoal. $\mathrm{Na}$ interpretação do país que o argumento faz supor, parece claro que a derrota dos movimentos sociais organizados e a ausência de organismos antissistêmicos potentes engendram a limitação do combate à luta pessoal 23 .

Curiosamente, a única data apresentada no argumento é o dia dos assassinatos do pai e do tio de Clodoaldo. Ela ocorreu dois dias após a derrota no Congresso Nacional da emenda Dante de Oliveira (25 de
[22] O ângulo escolhido pelo roteirista-diretor tem decerto perspectiva limitada no amplo material histórico-social do tema. A escolha por essa trajetória da vingança dos pequenos sitiantes, cujo destino foi selado pelos desmandos impunes do grande proprietário, indica que escapa aos propósitos deste filme trabalhar com outras formas de luta pela posse da terra e pela transformação da ordem político-social, atuantes no Brasil contemporâneo.

[23] Para não incorrer em generalizações facilitadoras, não custa lembrar que a derrota da mobilização popular que estava em curso nas décadas de 1950 e 1960 foi imposta pela violência da ditadura civil-militar. Por isso, muitos tinham a esperança (ou a ilusão) de que as eleições diretas trariam uma perspectiva de superação político-social. Com o restabelecimento da democracia, porém, acelerou-se o salto integrador no mercado internacional dos bens de consumo, bem como as políticas de facilitação ao acesso a eles por via do endividamento dos pobres. Os governos de Fernando Henrique Cardoso e especialmente de Lula, em suas duas gestões, não deixam dúvidas quanto a isso. A despolitização dos trabalhadores tem a ver também com programas que os tornaram orgulhosos consumidores, na órbita do fetiche da mercadoria. 
abril de 1984), que, como se sabe, propunha, com amplo apoio da população nas “Diretas já!", o restabelecimento das eleições diretas para presidente, pondo fim à sucessão de governos militares iniciada em 1964. O trabalho artístico com o material histórico sugere que, com eleições diretas, poderia ter havido um outro futuro. Ilusão burguesa ou confiança ingênua da voz das ruas sem clara definição de classe? De todo modo, os rumos da história contemporânea revelam que a oportunidade perdida, e anos depois concretizada, não trouxe o futuro ansiado.

Segundo o que a forma artística revela, a derrota da luta política (não só) dos camponeses e o fim das perspectivas de futuro, tal como entrevistas pela "tradição da formação" e pela militância política dos anos 1950/60, determinaram o advento do Brasil contemporâneo, cujos sistemas de poder, mantendo e aprofundando desigualdades, sem justiçar crimes das classes dominantes e do capital, fomentam vinganças pessoais, temores das classes média e alta, e não anunciam horizontes de transformação ou novas formas de organização política.

Decerto se pode questionar a interpretação que essa forma artística deu aos materiais históricos, até porque ela implica, do ponto de vista político, a subtração dos polos decisivos - as camadas dirigentes contemporâneas e a classe produtora das riquezas alheias. Mas ela intui o que está dado hegemonicamente nos polos intermediários nas grandes cidades: temor dos proprietários e desejo de vingança pessoal dos trabalhadores pobres. Os que torceram o nariz para a resolução dramática do enredo, que empolgava pelos flashes descontínuos, talvez não tenham dado a devida atenção ao fato de que, desde a primeira sequência, o filme se propunha a compreender a relação entre a derrota da promessa de transformação e o cenário atual. Só na cena do confronto essa relação se explicita, mesmo que isso custe ao conjunto a quase resolução do que se considerou o trunfo artístico de O som ao redor: a ameaça iminente, indefinida, descontínua. Mas, mesmo passível de questionamento político, o que se pode ler aqui é o diagnóstico de sintomas expressivos de nosso presente, sem que se exijam dele outros, talvez mais significativos politicamente, que já atuavam antes de 2012, como movimentos sociais organizados de luta pela terra e pelo teto, em todo o Brasil. Nem por isso o material estilizado perde sua força, ao elaborar uma visão profunda de princípios constitutivos da sociedade contemporânea: temores e fantasmagorias dos que estão assentados em suas posses, numa sociedade iníqua, versus revides dos humilhados e ações de vingança planejada pelos espoliados das terras que lhes garantiam sobrevivência e identidade.

O suspense que a trama armava, porém, fica apenas quase resolvido. À sequência que decifra as verdadeiras razões pelas quais se criou o ardil da empresa de segurança, segue-se, num corte abrupto, aquela 
em que Bia pretende resolver seu problema com os latidos do cachorro. Com planejamento prévio para evitar que se repitam as derrotas anteriores, ela comprara um saco de bombas de artifício. Na cena final do filme, toda a família, reunida no quintal do apartamento, compartilha a tarefa de acendê-las, no único momento de alegria coletiva do grupo. A alegria de provocar a dor insuportável no animal.

A montagem permite a associação entre cachorros e homens, entre mandantes de assassinatos e os que se desforram de cães. O grotesco da aproximação não deixa dúvidas. Nada de fato se altera, quando tudo se limita às vinganças pessoais, mais ou menos violentas.

O filme termina com as imagens da família de Bia. Resta apenas o som ao redor. Ouvem-se quatro tiros. Não se sabe de qual arma eles vêm, se da de Francisco, de Clodoaldo ou do irmão. Depois, a explosão das bombas. Como o som não é diegético, o final da história fica em aberto. Não sabemos o que ocorre nem com o patriarca nem com o cachorro nem com os irmãos. Além disso, os sons sucessivos de tiros e bombas nivelam a luta contra o inimigo. A não explicitação sobre os mortos, seéque houve mortos, é decisiva, pois, em qualquer dos casos, nada se resolve estruturalmente: outros cães continuarão a ladrar, outros "coronéis" continuarão a precisar de capangas, outros vingadores retornarão, e a cidade continuará a gerar ruídos confusos e a amortecer os confrontos. Nada se supera ou se aperfeiçoa, a não ser os estratagemas da vingança pessoal, sem poder de mobilização.

Antonio Candido, ao analisar o tema da vingança pessoal no Romantismo, considerou-o uma "espécie de quintessência do individualismo", que "foi, e de certo modo continua querendo ser, o eixo da conduta burguesa"24. Aqui, porém, o tema indica que o velho e insuperado arranco ancestral do revide serve à configuração da potência do indivíduo na contemporaneidade. Sinalizando a amplitude do mal-estar social, a revanche pessoal não engendra estratégias coletivas de luta nem ambiente organizativo. Limita-se às compensações simbólicas, ao pacto de sangue, à justiça selvagem.

$\mathrm{Na}$ trilha sonora do final, porém, ao desfilarem os créditos, sons de tambores retornam, dessa vez no ambiente da cidade atravessada por ruídos de aviões, buzinas de carros, roncos de motos, britadeiras, risos de crianças, numa verdadeira enumeração caótica da sonoplastia urbana. A cidade se constitui desse conjunto, na balbúrdia que oculta a marcha guerreira dos aprisionados ${ }^{25}$. O cineasta terá esperanças de que seu diagnóstico da vida urbana poderá produzir o retorno da luta?

A forma artística, que, insisto, figura a contemporaneidade como resultado da derrota de uma possibilidade histórica de transformação e testemunha a plena inserção do Brasil na órbita da ordem mundial, realimentando a reprodução do capital, das injustiças e dos temores de classe, anseia por mudanças. Sem ruptura radical entre o passado e
[24] "Da vingança". In: Tese e antítese. $2^{\text {a }}$ ed. São Paulo: Nacional, 1971, p. 13. 
Recebido para publicação em 25 de dezembro de 2014.

\section{NOVOS ESTUDOS}

101, março 2015

pp. 157-173 o presente, iniquidades continuam, bem como a promiscuidade entre o tradicional e o moderno, que o prolonga. Não há desagregação, mas agregação sob a lógica mercantil e, do lado dos oprimidos, aumento da rivalidade ressentida. Os conflitos e a iminência deles, nas fantasmagorias das classes média e alta, vinculam-se ao revanchismo vingativo. A visão contemporânea do país, aos olhos de Kleber Mendonça, é a visão pós-luta de classes (onde, no filme, estão as classes organizadas?), pós-nacional, e nela não há potência organizadora. Na era pós-ditadura, especialmente nas eras Fernando Henrique Cardoso e Lula, alegorizadas respectivamente na propaganda no cinema abandonado e na comemoração dos 13 anos da neta de Francisco (com mais uma pitada irônica, nos grupos de violeiros cujas músicas desagradam os jovens ali reunidos), a perspectiva do futuro se desmanchou. Os dias se anunciam como a reposição do de sempre. Só os míticos sons dos tambores parecem anunciar que algo - da ordem da fantasmagoria pode instalar-se entre os ruídos da vida contemporânea. A solução, ex machina, premonitória ou desejante, anseia por algo, mesmo que regressivo. Mas de onde virão esses sons? Em 2012, Kleber Mendonça Filho os ouvia imaginariamente. Os acontecimentos e as palavras de ordem de junho de 2013, já distantes do jargão tradicional das esquerdas, terão lhe trazido outra perspectiva? Os ataques diretos à propriedade, pelos black blocks, trouxeram à cena da vida real a politização da violência?

IVONE DARÉ RABELLO é professora sênior do Departamento de Teoria Literária e Literatura Comparada da FFLCH da Universidade de São Paulo. 